\section{From Prehistory} to the Present

Learn about the human past from prehistory to the present day.

Develop new skills and polish others.

Whatever your experience or interests, there has never been a better time to join one of the top archaeology departments in the country.

Achieved top ratings for teaching in recent national surveys (QAA and NSS).

Identified as one of the top ten research institutions in Britain (RAE 2008).

Access to the wealth of resources and professional expertise that the city of York has to offer.

CPD, short courses and part time options for those who have to balance their studies with other commitments.

\section{BA/BSC}

Archaeology BA and BSC

Bioarchaeology BSC

Historical Archaeology BA

\section{MA/MSc}

Archaeological Information Systems Archaeology of Buildings

Bioarchaeology

Coastal and Marine Archaeology

Conservation Studies (Historic Buildings) Cultural Heritage Management

Digital Heritage

Early Prehistory

Field Archaeology

Historical Archaeology

Historic Landscape Studies

Landscape Archaeology

Medieval Archaeology

Mesolithic Studies

Zooarchaeology

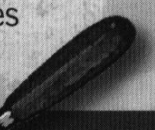

Postgraduate

STUDENTSHIPS

\& BURSARIES

AVA ILABLE

ARCHAEOLOGY AT

THE University of $y$ ork
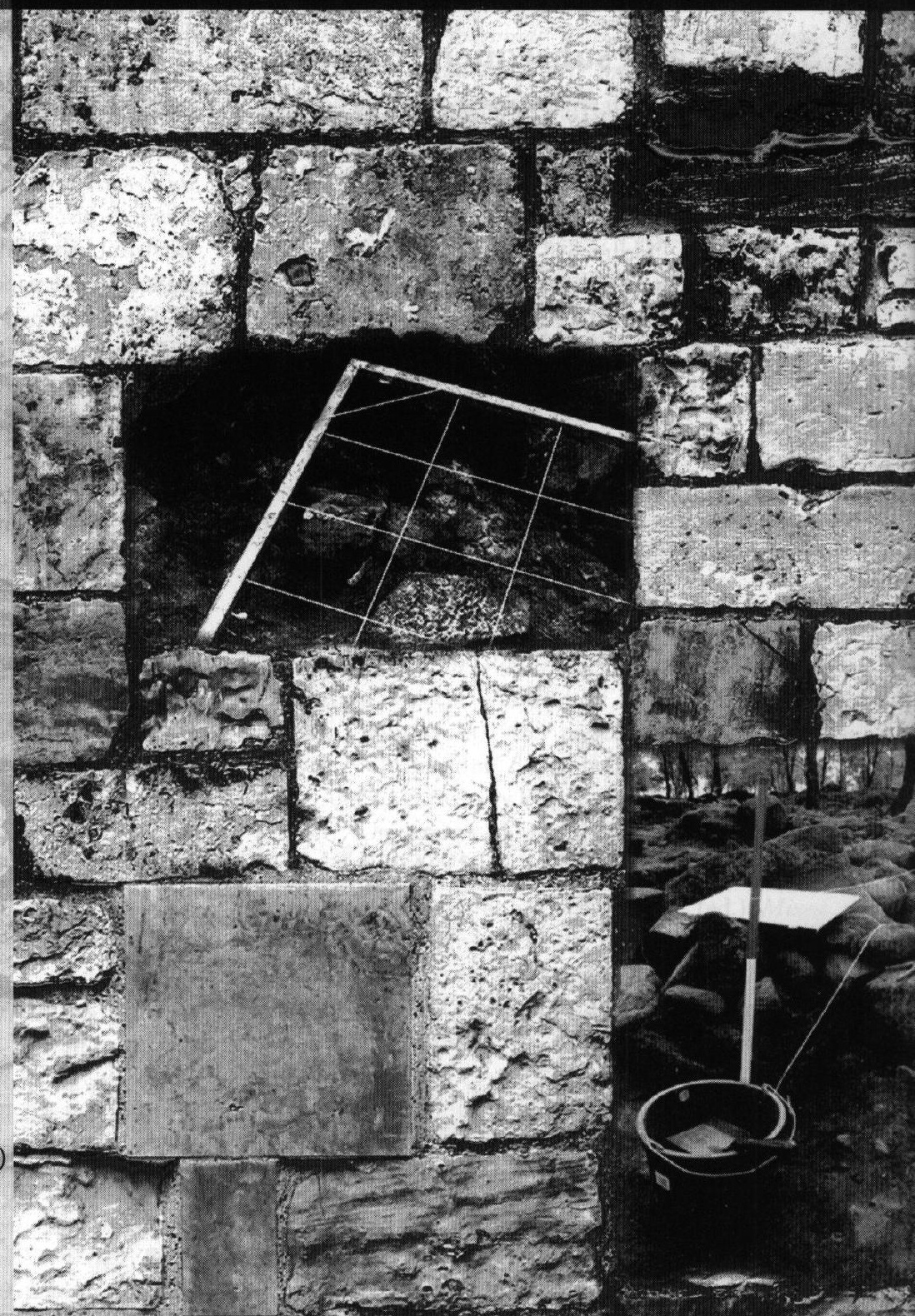

औ

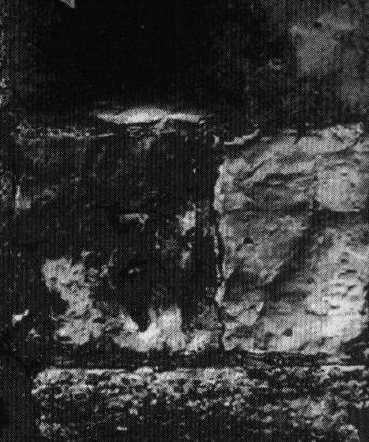

For further details, see our website or contact:

Department of Archaeology University of York

King's Manor

York YO1 7EP

UK www.york.ac.uk/archaeolog archaeology@york.ac.uk

Tel: +44 (0) 1904433903 +44 (0) 1904433963 


\section{Notes for contributors}

Antiquity aims to report new archaeological research, method and issues of international significance in plain language to a broad academic and professional readership. The journal is published quarterly in March, June, September and December.

Submissions are invited in the following categories: Research (max. 5000 words), Method and Debate (each max. 3000 words). Word limits include all text, tables, references and figure captions.

Antiquity uses a secure and confidential online submission and peer-review system. Detailed help on how to submit is available both prior to submission and throughout the submission process. To submit a manuscript please visit our website at http://antiquity.ac.uk/contribute/ contribute.html where you will find a link to the submission site and full Instructions for authors.

Wherever possible manuscripts should be submitted as a single Adobe PDF document containing all text, tables and figures but excluding any covering letter. If you cannot submit your manuscript as a PDF, you may submit separate text and graphics files. If your paper is accepted for publication, you will be asked to provide separate high-resolution, publication-quality graphics, in TIFF or EPS format. It is therefore best for the initial submission to create any graphics using applications that are capable of preparing acceptable TIFF or EPS formats. Resolutions must be $300 \mathrm{dpi}$ or higher and image dimensions should be either half-page width $(65 \mathrm{~mm})$ or full-page width $(135 \mathrm{~mm})$. The maximum acceptable height is $185 \mathrm{~mm}$. Maps and plans must include an accurate scale and north point.

As part of the submission process authors will be required to confirm that the substance of the content presented has not been published previously and is not currently being considered for publication elsewhere.

We prefer to receive submissions in English but can consider submissions in French, German, Italian and Spanish where submitting in English is not possible. (Accepted papers are translated free of charge and published in English.)

All submissions are considered by the Editor in the first instance. Suitable papers are peerreviewed by a minimum of two experts. If you are unsure whether a paper is suitable for Antiquity, please contact the Editor prior to submission (editor@antiquity.ac.uk).

\section{Project Gallery (http://antiquity.ac.uk/ projgall/)}

The Project Gallery (max. 1000 words +6 figures) is part of Antiquity's online Bulletin and is intended to showcase projects and ideas of international status. The Project Gallery also welcomes contributions to archaeological historiography and responses to published articles. Please note that the Editor will not accept reports about local or regional surveys, sites or artefacts unless of wider significance; articles of local and regional interest should be properly directed to the national records and journals of the country concerned. Project Gallery articles are not normally peerreviewed but the Editor may seek external advice.

\section{Books for review}

We welcome books for review on archaeology and associated research. Please send books to the Reviews Editor, Dr Madeleine Hummler, at Antiquity, King's Manor, York YO1 7EP, UK (reviews@antiquity.ac.uk). 


\section{Contact Details}

\section{AntIQUITY 2012 Subscription Order Form}

Name:

Delivery Address (include post/zip code and country)

Telephone:

Fax

Email:

Premium: printed and online version of the journal AND access to the electronic archive of previous issues back to 1927

Combined: printed and current online versions of the journal

Print only: printed version of the journal

Online only: online current version of the journal

Journal Subscription

\begin{tabular}{|l|c|c|c|c|c|c|c|c|c|c|}
\hline 2012 & \multicolumn{4}{|c|}{ Institutional } & \multicolumn{5}{c|}{ Individual } \\
\cline { 2 - 12 } & Tick box & UK $£$ & VAT (see note) & US $\$$ & $€$ & Tick box & UK £ & VAT (see note) & US \$ & $€$ \\
\hline Premium & $\square$ & 340 & $(+£ 48.32$ VAT) & 573 & 461 & $\square$ & 77 & (+£8.24 VAT) & 143 & 111 \\
\hline Combined & $\square$ & 191 & $(+£ 18.52$ VAT) & 320 & 254 & $\square$ & 61 & (+£5.04 VAT) & 113 & 89 \\
\hline Print only & $\square$ & 171 & n/a & 286 & 226 & $\square$ & 54 & n/a & 102 & 84 \\
\hline Online only & $\square$ & 161 & $(+£ 32.20$ VAT) & 272 & 220 & $\square$ & 38 & (+£7.60 VAT) & 72 & 57 \\
\hline For airmail delivery add & $\square$ & 25.65 & & & & $\square$ & 25.65 & & & \\
\hline
\end{tabular}

Note: VAT will be due on the online element of subscriptions from the UK and from non-registered subscribers elsewhere in the EU.

EU customers should provide their VAT number:

\section{Method of Payment}

$\square$ One off payment for 2012 only by Credit Card
Card: Visa / MasterCard / Eurocard / Switch / Connect

Card No:

Valid from: Expiry Date

Issue No:

Card holder's name (as it appears on card)

Card holder's address (if different to delivery)

Signature

Date

Please make cheque payable to Portland Customer Services

Cheque or postal order

Bank Transfer

Make payment to Portland Customer Services, NatWest Bank PIc, 25 High Street,

Colchester CO1 1DG, UK. Account \# 01863630 - Sort Code: 60-06-06

Please include full name and reason for transfer i.e. Antiquity subscription and supply us with details of your transfer, date of transaction, amount and the bank from which you are transferring.

Direct Debit

Please send me a direct debit mandate form

Please send me a proforma invoice

Discounts may be available for students and institutions in developing countries. Please apply to the Editor for details.

Please send form and payment to:

Portland Customer Services, Commerce Way, Colchester CO2 8HP, UK

Tel: +44 (0)1206 796351 Fax: +44(0)1206 799331

email: sales@portland-services.com www.portland-services.com 


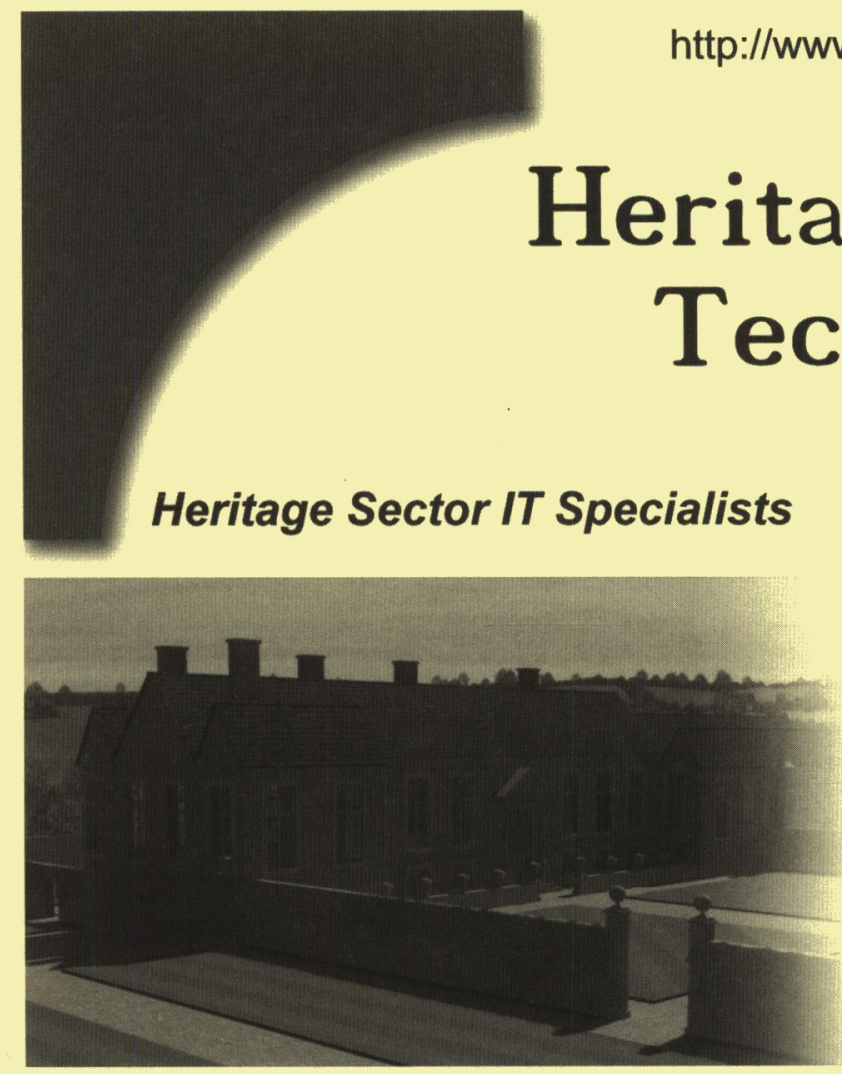

\section{D Visualisation \\ $\Gamma$ Digital visualisation of objects, buildings \& landscapes \\ Photo-realistic, high quality historical reconstructions}

Services for visitor attractions, academia \& commercial projects

FIndividually tailored to

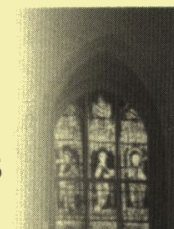
to fit all requirements \& budgets

$\Gamma$ Services also include web design \& digital archaeological support

Heritage Technology specialises in creating highly realistic 3D visualisations from historical \& archaeological data. Digital reconstruction is a proven technique in both academic \& commercial archaeology for portraying often complex spatial \& temporal data in an accessible and engaging way. Explore the possibilities at: 


\section{Archaeopress}

Gordon House, 276 Banbury Road, Oxford OX2 7ED England Tel/Fax: +44 1865311914 e-mail: bar@archaeopress.com http: //www.archaeopress.com

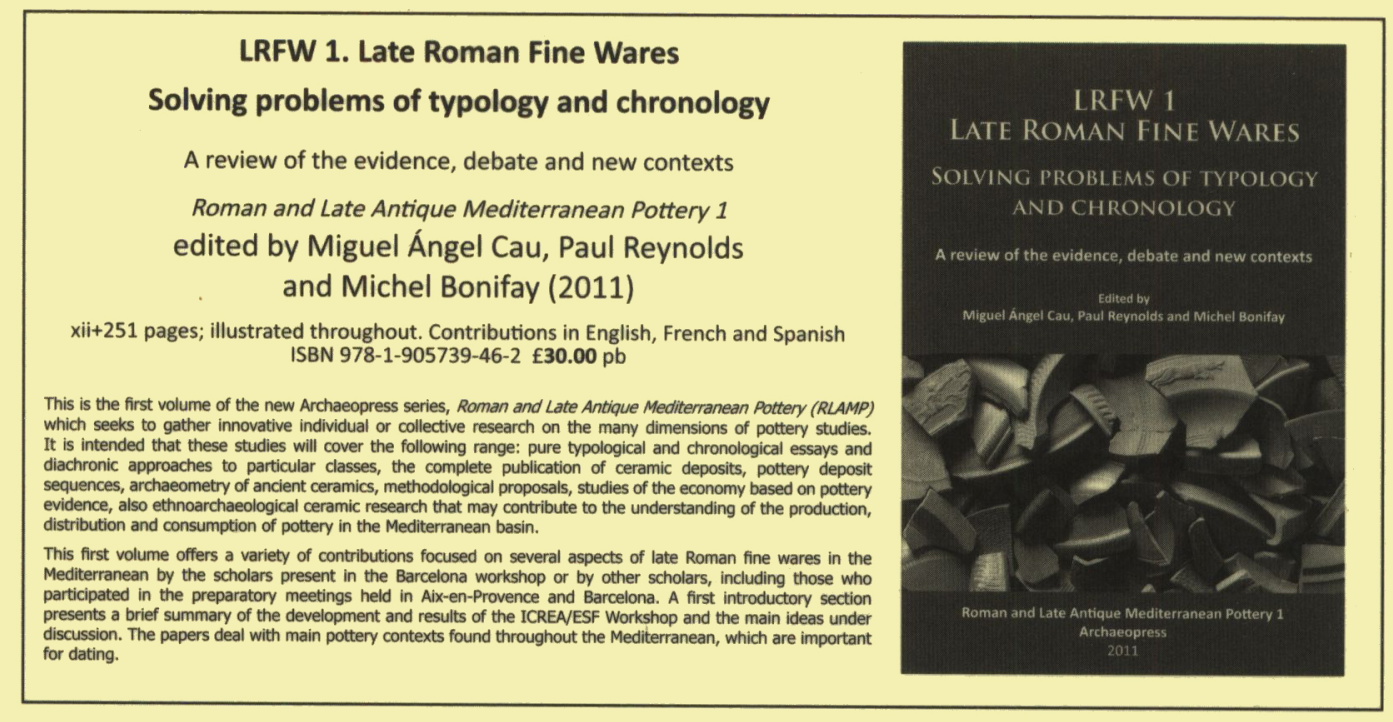

\section{WreckProtect \\ Decay and protection of archaeological wooden shipwrecks \\ edited by Charlotte Gjelstrup Björdal and David Gregory with assistance from Athena Trakadas (2011) \\ i-viii, 154 pages illustrated throughout in colour ISBN 978-1-905739-48-6 £19.95 hb}

This book stems from the results of an interdisciplinary European Union supported research project, WreckProtect which investigated the decay and preservation of wooden shipwrecks under water in the Baltic Sea. It is is not limited to the decay of wrecks in the Baltic alone and is aimed at all stakeholders with a vested interest in the protection of the underwater cultural heritage including marine archaeologists, conservators, engineers, and students in related fields at universities around the world.

The book includes chapters on the anatomy and structure of wood and the physical and biological decay of shipwrecks under water. Well-known shipwrecks in the Baltic Sea are introduced, focusing upon their state of preservation and are compared to finds typically found in the North Sea and the Mediterranean. Microbial decay processes and their identification in both sediments and the water column are also discussed and related to other natural decay processes, as well as human impacts. Finally, a summary of available methods for the in-situ protection of wrecks are evaluated and a cost- benefit analyses of in-situ preservation versus conventional raising and conservation are given.

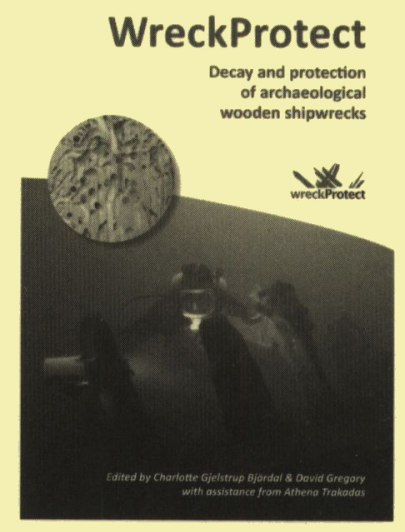

\section{B.A.R. \\ British Archaeological Reports}

For all Archaeopress BAR titles with short summaries go to www.archaeopress.com

Sign up to our monthly ALERTS SERVICE via our above website homepage

BAR titles can be ordered from Hadrian Books, 122 Banbury Road, Oxford OX2 7BP, UK www. hadrianbooks.co.uk 